\title{
COMPACT REFERENCE UVC LED SOURCE
}

\author{
S.V. Nikanenka, A.V. Danilchyk, E.V. Lutsenko \\ ${ }^{1}$ B. I. Stepanov Institute of Physics National Academy of Sciences of Belarus, Minsk, Belarus, \\ s.nikonenko@dragon.bas-net.by
}

\begin{abstract}
There are a number of problems in metrological insurance in the UV spectral region. First, it is a significant reduction in the accuracy of the transfer of quantities from national standards of the corresponding optical quantities to working units in the CIE UV ranges. Second, when measuring in the UV CIE ranges, it is necessary to use a power meter with constant spectral sensitivity inside these ranges and zero outside it, which is very problematic due to the lack of high-quality UV filters. Third, the accuracy of the results of measuring optical characteristics of UV radiation is reduced significantly by difference in spectral distributions of the radiation intensity of the test and reference radiation sources. One of the promising ways to improve the accuracy of measurements in the UV spectral region is the use of reference radiation sources created based on LEDs, due to their stability and long lifetime.

A compact reference UVC source based on state-of-the-art commercially available LED were designed and constructed at B.I. Stepanov Institute of Physics NAS of Belarus. The paper presents the design and results of the study of the optical characteristics of the radiation of the reference UVC LED source. A power density of the compact reference UVC LED source is $>200 \mu \mathrm{W} / \mathrm{cm}^{2}$, which provides a fine level for calibrating UV radiometers in range $\mathrm{UVC}$.
\end{abstract}

Keywords: ultraviolet; UV-LED; reference radiation source; measurement.

\section{Introduction}

UV radiation is widely used to solve various engineering and scientific problems. Efficiency, quality and safety of work performed using UV radiation is largely determined by the quality of measurement.

There are a number of problems in metrological insurance in the UV spectral region. First, it is a significant reduction in the accuracy of the transfer of quantities from national standards of the corresponding optical quantities to working units in the CIE UV ranges. Second, when measuring in the UV CIE ranges, it is necessary to use a power meter with constant spectral sensitivity inside these ranges and zero outside it, which is very problematic due to the lack of high-quality UV filters. Third, the accuracy of the results of measuring optical characteristics of UV radiation is reduced significantly by difference in spectral distributions of the radiation intensity of the test and reference radiation sources.

One of the promising ways to improve the accuracy of measurements in the UV spectral region is the use of reference radiation sources created based on LEDs, due to their stability and long lifetime. Earlier, the Institute of Physics of the NAS of Belarus has developed a number of reference radiation sources for the CIE UV ranges based on LEDs [1 - 3]. In the article, the design of the created new reference CIE UVC LED source describes.

\section{Design UVC LED source}

A reference UVC LED source (RUVCS) based on state-of-the-art commercially available one LED emitting at wavelength of $265 \mathrm{~nm}$.
The source operates as follows: the injection current is supplied to the LED chip 1, the temperature of which is regulated by the Peltier element 4 based on the resistance value of the thermistor 5 . The heat generated by the Peltier element is removed through the base 6 and is additionally cooled by a radiator of water or air cooling 11 . The temperature controller Arroyo TECSource 5305 was used to stabilize temperature of the RUVCS. The highly stabilized current source Arroyo 4302 LaserSource was used to power UV LED.

\section{Optical characteristics of the source}

The measurement of optical characteristics of LEDs and RUVCS was carried out on setup for the measurement of optical characteristics of UV-NIR SSL sources radiation [4]. The measurements were performed at $25^{\circ} \mathrm{C}$ stabilized temperature.

The inset in figure 2 shows the angular distribution of the radiation intensity of the LED. As can be seen from the far field, the radiation intensity is approximately the same within the cone $\pm 10^{\circ}$. But the radiation intensity level of UVC LED is low for calibrating of UV radiometers. Therefore, a correcting lens 13 and a holographic diffuser 9 are included in the design of the reference source (Fig. 1).

The figure 2 shows the angular distribution of the radiation intensity of the RUVCS without holographic diffuser. As can be clearly seen from the figure, the lens system of the RUVCS transforms the radiation intensity of the LED into radiation with a half-width of $\pm 3^{\circ}$ at half-maximum intensity. 


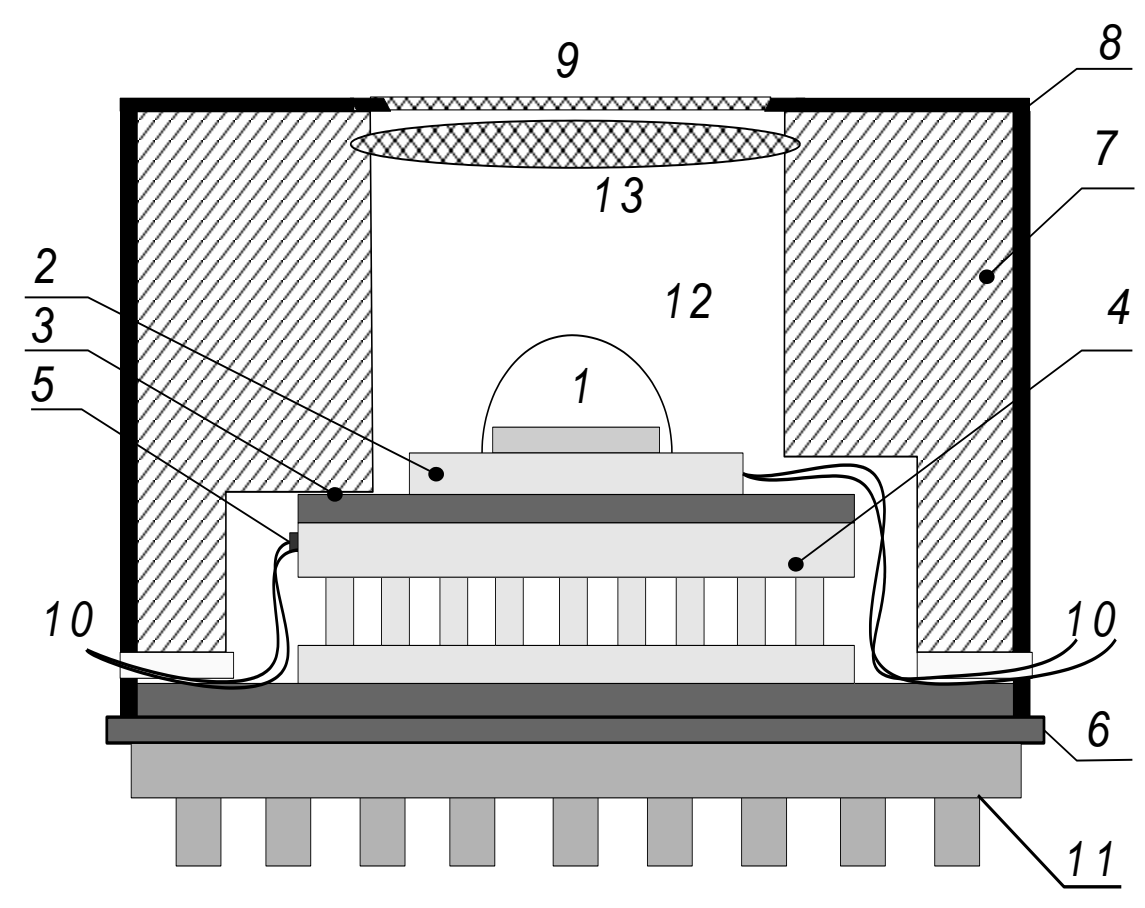

Fig. 1. Picture of reference UVC LED source

Moreover, in the viewing angle of $\pm 2^{\circ}$, the RUVCS intensity distribution is approximately uniform. Such a configuration of the lens system provides approximately the same intensity (necessary for calibrating the radiometer) on a $4 \times 4 \mathrm{~cm}$ site at a distance of $50 \mathrm{~cm}$ from the radiation source. The observed changes in the radiation intensity are because the LED lens projects an image of the chip to infinity. The changes of intensity corre- sponds to the electrode of the LED chip. To reduce the intensity heterogeneity in this angle, we used a holographic diffuser. As can be seen from Fig. 2, only the use of the correcting lens made it possible to increase the power density of the RUVCS by an order of magnitude and significantly reducing the inhomogeneity of radiation intensity in the far field.

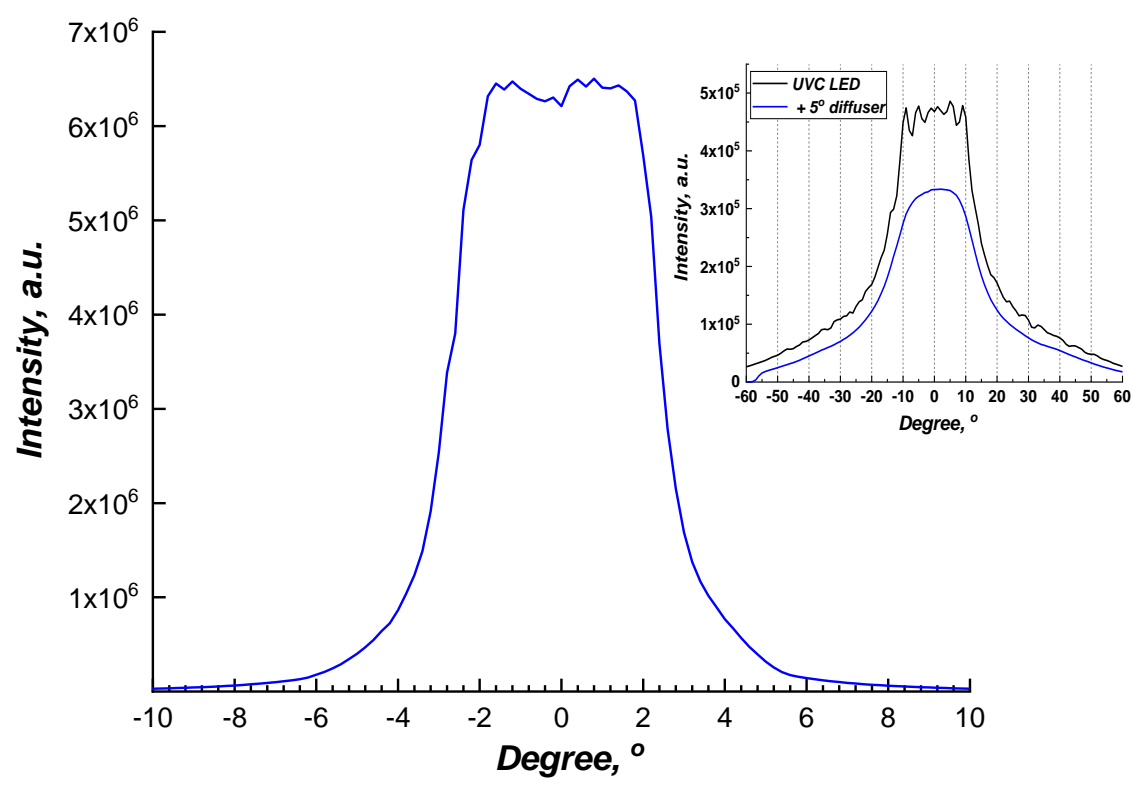

Fig. 2. Radiation intensity of reference UVC LED source as a function of angle. Inset shows radiation intensity of UVC LED and UVC LED at $5^{\circ}$ diffuser 
Fig. 3 shows the dependence of the power density on the injection current at measurement distance $50 \mathrm{~cm}$ from RUVCS and the LED chip. As can be seen in the inset in Fig. 3, the maximum quantum efficiency is achieved at an injection current of $350 \mathrm{~mA}$. This corre- sponds to a power density of $>200 \mu \mathrm{W} / \mathrm{cm}^{2}$, which provides a fine level for calibrating UV radiometers. Therefore, we recommend this injection current level for source operation. With this injection current, the LED lifetime should increase from 10000 to about 50000 hours.

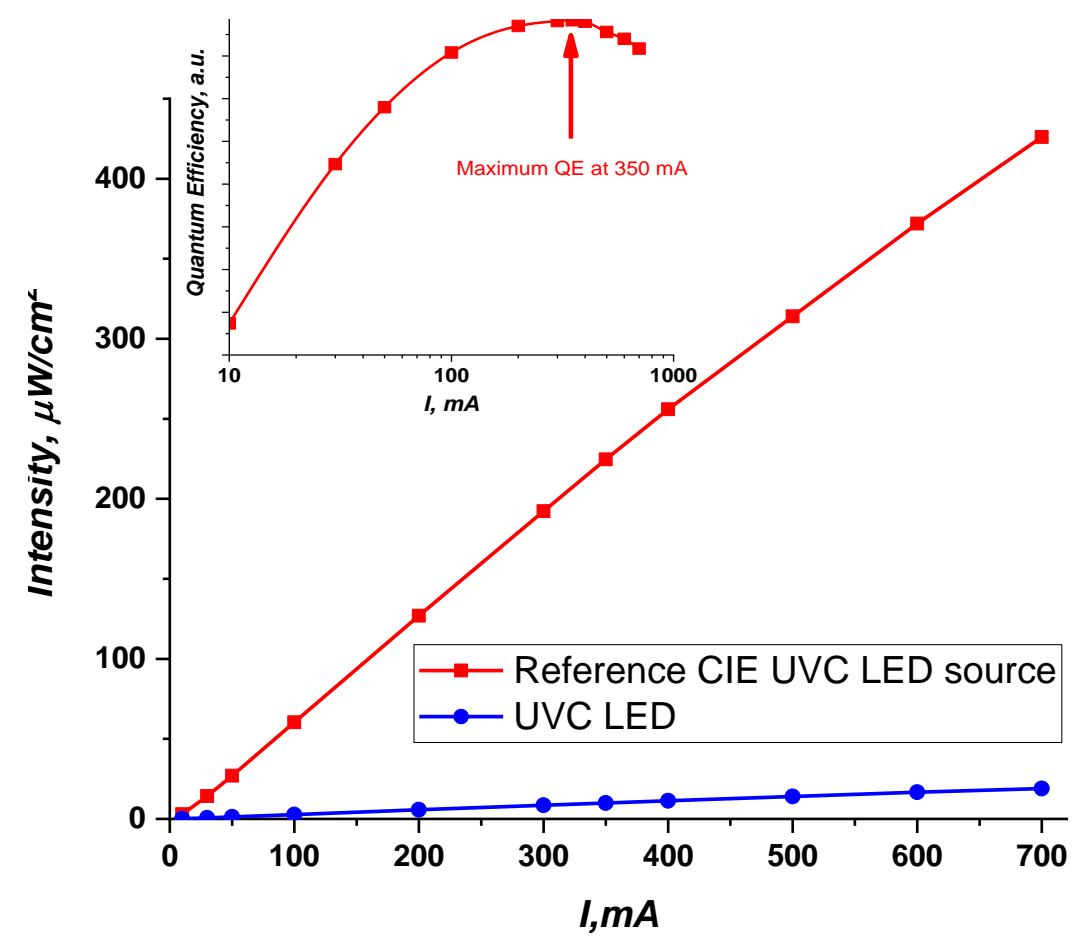

Fig. 3. Intensity of reference UVC LED source as a function of injection current. Inset shows radiation intensity of UVC LED and UVC LED at $\pm 5^{\circ}$ diffuser

As can be seen from Fig. 4, the radiation intensity of RUVCS are about only $5 \%$ at the boundary between UVC and UVB ranges. At selected level of injection current, the radiation spectrum is independent of the viewing angle within the essential radiation intensity levels $\left( \pm 3^{\circ}\right)$.

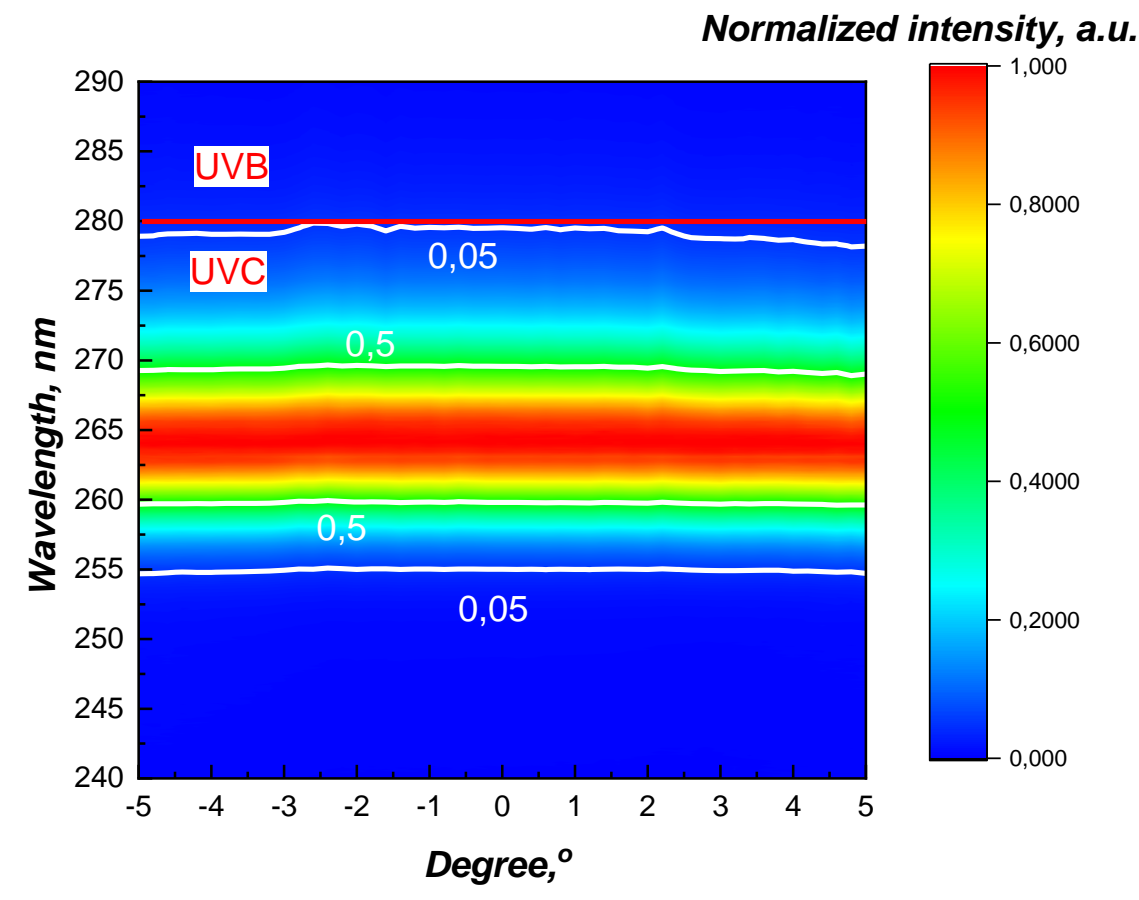

Fig. 4. 2D color mapping of reference UVC LED source normalized spectra as a function of angle 
Fig. 5 show the distribution $( \pm 2 \%)$ of the radiation intensity of RUVCS without holographic diffuser in the working area at distance $50 \mathrm{~cm}$. The used of $1^{\circ}$ holographic diffuser in the RUVCS leads to an improvement in the uniformity of the distribution of the radiation intensity density up to $\pm 1 \%$.

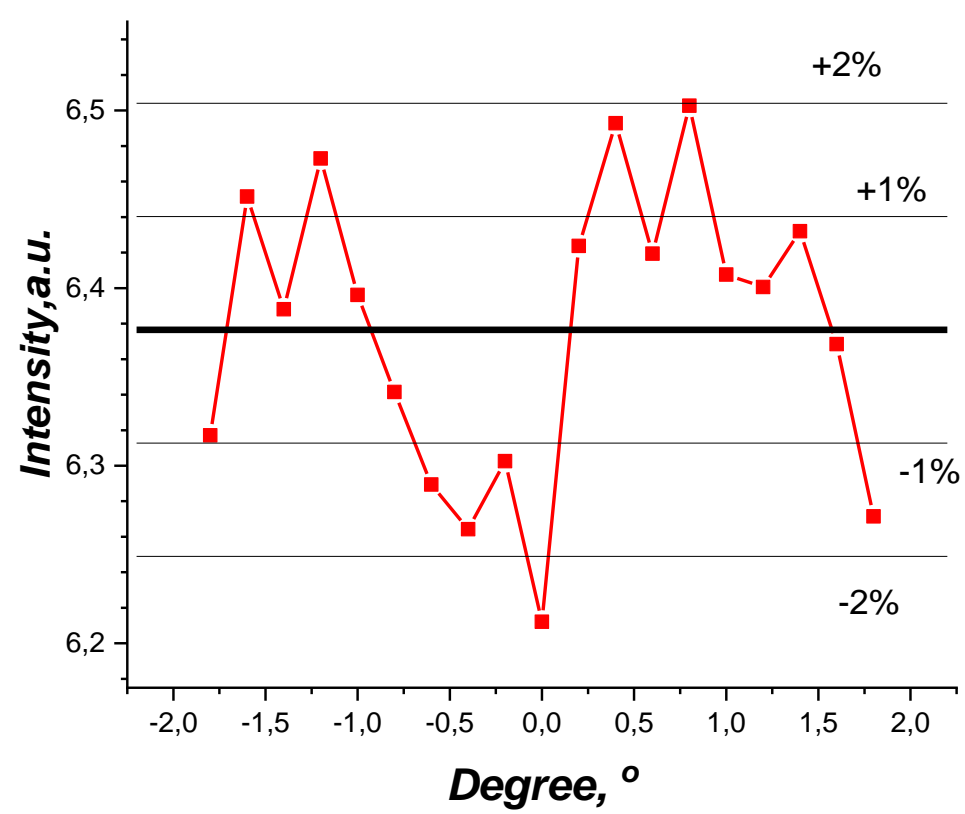

Fig. 5. Intensity of reference UVC LED source in the working area

\section{Conclusions}

A compact reference UVC source based on stateof-the-art commercially available LED were designed and constructed at B.I. Stepanov Institute of Physics NAS of Belarus. The paper presents the design and results of the study of the optical characteristics of the radiation of the reference UVC LED source. A power density of the compact reference UVC LED source is $>200 \mu \mathrm{W} / \mathrm{cm}^{2}$, which provides a fine level for calibrating UV radiometers in range UVC.

\section{Аннотация}

В метрологическом обеспечении в УФ-области спектра существует ряд проблем. Во-первых, это значительное снижение точности передачи размера величин от национальных эталонов соответствующих оптических величин рабочим средствам измерений в УФ-диапазонах СIE. Во-вторых, при измерении в УФ-диапазонах CIE необходимо использовать средства измерений оптической мощности имеющих постоянную спектральную чувствительностью внутри этих диапазонов и нулевую за его пределами, что очень проблематично из-за отсутствия качественных УФ-фильтров. В-третьих, точность результатов измерения оптических характеристик УФ-излучения существенно снижается из-за различия в спектральных распределениях интенсивности излучения испытуемого и эталонного источников излучения. Одним из перспективных способов повышения точности измерений в УФобласти спектра является использование эталонных источников излучения, созданных на основе светодиодов, благодаря их стабильности и длительному сроку службы.

Компактный эталонный источник ультрафиолетового излучения для ультрафиолетового диапазона CIE C, на основе коммерчески доступных современных светодиодов, разработан и изготовлен в Институт физики имени Б.И. Степанова НАН Беларуси. В докладе рассмотрена конструкция и результаты исследования оптических характеристик излучения эталонного светодиодного источника излучения. Плотность мощности компактного эталонного светодиодного источника на расстоянии 500 мм составляет > 200 мкВт/см², что обеспечивает необходимый уровень для калибровки УФрадиометров в УФ диапазоне CIE C.

Ключевые слова: ультрафиолет; ультрафиолетовый светодиод; эталонный источник излучения; измерение. 


\section{Анотація}

У метрологічного забезпечення в УФ-області спектра існує ряд проблем. По-перше, це значне зниження точності передачі розміру величин від національних еталонів відповідних оптичних величин робочим засобам вимірювань в УФ-діапазонах CIE. По-друге, при вимірюванні в УФ-діапазонах CIE необхідно використовувати засоби вимірювань оптичної потужності мають постійну спектральну чутливість всередині цих діапазонів і нульову за його межами, що дуже проблематично через відсутність якісних УФ-фільтрів. Потретє, точність результатів вимірювання оптичних характеристик УФ-випромінювання істотно знижується через відмінності в спектральних розподілах інтенсивності випромінювання випробуваного і еталонного джерел випромінювання. Одним з перспективних способів підвищення точності вимірювань в УФ-області спектра є використання еталонних джерел випромінювання, створених на основі світлодіодів, завдяки їх стабільності і тривалого терміну служби.

Компактний еталонний джерело ультрафіолетового випромінювання для ультрафіолетового діапазону CIE C, на основі комерційно доступних сучасних світлодіодів, розроблений і виготовлений в Інституті фізики імені Б.І. Степанова НАН Білорусі. У доповіді розглянута конструкція і результати дослідження оптичних характеристик випромінювання еталонного світлодіодного джерела випромінювання. Щільність потужності компактного еталонного світлодіодного джерела на відстані 500 мм становить $>200$ мкВт / см², що забезпечує необхідний рівень для калібрування УФ-радіометрів в УФ діапазоні СІЕ С.

Ключові слова: ультрафіолет, ультрафіолетовий світлодіод, еталонний джерело випромінювання, вимір.

\section{References}

1. Nikanenka S.V., Lutsenko E.V., Danilchyk A.V., Zhdanovski V.A., Kreidzich A.V., Rzheutski M.V. A practical method for determination of averaged spectral radiance of UV LED. CIE 216:2015. Proc. 28th Session of the CIE, Manchester, UK, 28 June - 4 July 2015. - Manchester: CIE, 2015. 2015. Vol. 1. Part 2. P. 1396-1400.

2. Scums D.V., Danilchyk A.V., Zhdanovskii V.A., Kreidzich A.V., Lutsenko E.V., Nikanenka S.V. New type of source for luxmeters calibration. CIE 216:2015. Proc. 28th Session of the CIE, Manchester, UK, 28 June - 4 July 2015. 2015. Vol. 1. Part 2. P. 1382-1384.

3. Nikanenka S.V., Lutsenko E.V., Danilchyk A.V., Zhdanovski V.A., Kreidzich A.V., Rzheutski M.V. Reference hemispherical UVA LED source. New Developments and Applications in Optical Radiometry (NEWRAD 2017): Proc. 13th Internat. Conf., Tokyo, Japan, 13-16 June 2017. 2017. P. 114-115.

4. Nikanenka S.V., Danilchyk A.V., Dlugunovich V.A., Kreidzich A.V., Rzheutski M.V., Scums D.V., Lutsenko E.V. Reference UV LED Sources. Smart Light- ning for Better Life: Proc. Conf. at the CIE Midterm Meeting 2017, Jeju Island, Republic of Korea, 20-28 October 2017. - CIE, 2017. P. 984-989. doi: 10.25039/x44.2017.PO43

5. Nikanenka S.V., Danilchyk A.V., Lutsenko E.V. Reference UVB and UVC LED sources. Ukrainian Metrological Journal. 2019. № 1. P. 47-53. doi:10.24027/23067039.1.2019.164713

6. Nikanenka S.V., Danilchyk A.V., Lutsenko E.V. Compact reference UV-LEDs sources with conical diffuse reflectors. CIE x046:2019, Proc. 29th Session of the CIE Washington D.C., USA, June 14 - 22, 2019. 2019. Vol. 1, Part 2, P. 1193-1194/4. doi: 10.25039/x46.2019.PO100

7. Nikanenka S.V., Danilchyk A.V., Dlugunovich V.A., Zhdanovskii V.A., Kreidzich A.V., Liplianin A.A., Rzheutski M.V., Lutsenko E.V. Setup for measurement of the optical characteristics of UV-NIR solid-state light sources emission. New Developments and Applications in Optical Radiometry (NEWRAD 2014): Proc. 12th Intern. Conf., Espoo, Finland, 24-27 June 2014. 2014. P. 350351. 